\title{
Za Boskim Oblubieńcem. Teologiczno-liturgiczny sens dziewictwa konsekrowanego
}

W coraz większym stopniu w dzisiejszym świecie dziewictwo jawi się jako pozbawione znaczenia i specyficznego celu. Nie można wykluczyć, że eliminuje się je w sposób świadomy, by tym samym pomniejszyć Ewangelię Chrystusa, która zawiera nie tylko niewątpliwą afirmację dziewictwa, ale dokonuje jego niewątpliwego wywyższenia, co potwierdzi szczególnie sobór trydencki mało zauważanym dogmatem:

Gdyby ktoś mówił, że stan małżeński trzeba stawiać przed stanem dziewictwa lub celibatu, i że nie jest lepiej i szczęśliwiej pozostać w dziewictwie lub w celibacie niż łączyć się małżeństwem

- niech będzie wyklęty ${ }^{1}$.

Sięga się w tych działaniach o charakterze deprecjonującym do rozmaitych metod, począwszy od ośmieszenia - które dowodzi oczywiście infantylizmu etycznego i kulturowego - aż do otwartego zwalczania. Rani się w ten sposób nie tylko moralność, ale także ogólnoludzką kulturę, której moralność jest podstawą, główną treścią i najwyższą gwarancją jej trwałości. Równocześnie, z wielu racji i z wielu stron, odkrywa się, że życie w sposób dobrowolny, pełny i osobowy poświęcone sprawie królestwa Bożego w niczym nie ogranicza człowieka, ale go dopełnia i wypełnia; nie jest tylko rezygnacją, ale staje się szlachetnym i umacniającym osobowo darem, przynoszącym konkretne owoce duchowe i kulturowe. Nie jest tym, co negatywne, ale tym, co w najwyższym stopniu pozytywne, lecz, aby to dostrzec, trzeba szukać tego, co Karol Wojtyła nazywał „pełnym sensem czystości”2. Jedną z dróg umożliwiającą odkrywanie tego sensu jest eklezjalne rozumienie dziewictwa konsekrowanego, na które chcemy spojrzeć w niniejszym opracowaniu.

${ }^{1}$ Sobór trydencki, Kanony o sakramencie matżeństwa, Kan. 10, [w:] Dokumenty soborów powszechnych, t. 4, red. A. Baron, H. Pietras, Kraków 2004, s. 719. Na temat kontekstu wypowiedzi soborowej por. A. Franzen, Celibato e matrimonio dei preti nelle dispute del secolo XVI, Roma 1971.

${ }^{2}$ K. Wojtyła, Miłość i odpowiedzialność, Lublin $19866^{4}$, s. 150. 


\section{Założenia metodologiczne}

Na początku zachodzi potrzeba określenia niektórych założeń metodologicznych, które pozwolą pogłębić naturę chrześcijańskiej konsekracji dziewictwa ${ }^{3}$. Opieramy się w tych rozważaniach na perspektywach teologiczno-liturgicznych wyznaczonych przez Ordo consecrationis virginum i Ordo professionis religiosae. Wychodzimy w ten sposób od stwierdzenia, zasadniczego dla określenia natury i znaczenia wszelkich rzeczywistości chrześcijańskich, że najwłaściwsze i najbardziej adekwatne kryterium znajdują one wtedy, gdy dla ich zrozumienia odwołamy się do zasady: lex orandi - lex credendi. Oznacza to, że nasze poszukiwanie opiera się zasadniczo na depositum fidei, będącym przedmiotem modlitwy i świadectwa Kościoła, a więc na rzeczywistości faktycznie przeżywanej na gruncie wiary, mającej bezpośrednie odniesienie do Boga i do człowieka ${ }^{4}$.

Zacznijmy więc od kwestii dziewictwa, by określić przedmiot naszych rozważań. W tej kwestii nauczanie Kościoła, w punkcie wyjścia, opiera się właściwie na dwóch zasadniczych założeniach, których cechą charakterystyczną jest pozytywne rozumienie dziewictwa.

1. Dziewictwo konsekrowane jest więc rzeczywistością pozytywną w sferze wiary celebrowanej (liturgia). Jest to równoznaczne ze stwierdzeniem, że działanie liturgiczne odgrywa pierwszorzędną rolę w stosunku do dziewictwa chrześcijańskiego. Jest ono ukazywane w liturgii przede wszystkim jako dar, którego udzielają człowiekowi Osoby Boże. Darem jest wiara, która w działaniu liturgicznym jest prowadzona na swój szczyt za pośrednictwem celebracji; darem jest również dziewictwo przeżywane i celebrowane jako rzeczywistość chrześcijańska, ponieważ jest złączone $\mathrm{z}$ wiarą i nią napełnione.

2. Dziewictwo konsekrowane nabiera w środowisku liturgicznym wszystkich cech charakterystycznych, zarówno ontologicznych, jak i dynamiczno-działaniowych, właściwych dla liturgii. Pozwala ona zrozumieć, że dziewictwo nie jest tylko wynikiem wysiłku ascetycznego ani nie sprowadza się do jakiejś fizycznej ozdoby wierzącego, ale obejmuje całą jego osobę i wszystkie wymiary jej wyrażania się, która, odnowiona przez sakramenty, odnawia siebie przez osobiste zaangażowanie, wspisując się w ten sposób w dzieje zbawienia.

Staje się więc jasne, że można tutaj mówić o konsekracji, gdyż jest ona zrozumiała tylko w relacji do dynamizmu wiary. Oznacza ona nowe wyrażenie i umocnienie trzech poziomów właściwych dla wiary chrześcijańskiej. Nie tylko wierzy się, że Bóg

\footnotetext{
${ }^{3}$ Nie ulega wątpliwości, że sprawą, którą należałoby tu również uwzględnić, jest relacja małżeństwa i dziewictwa w rozumieniu katolickim, zwłaszcza w odniesieniu do kwestii czystości. Ze względu jednak na ramy podejmowanego zagadnienia odsyłamy do opracowań dobrze ujmujących tę problematykę. Oprócz cytowanej pracy K. Wojtyły, por. np. M. Thurian, Mariage et célibat, Neuchâtel 1964; A. Chapelle, Sexualité et sainteté, Bruxelles 1977.

${ }^{4}$ Por. L. Scheffczyk, Lex credendi - lex orandi. La liturgia, norma di fede, [w:] Musicae sacrae mysterium, red. R. Schumacher, Roma 1996, s. 14-23.
} 
jest Trójcą (credo Trinitatem) i przyjmuje to wszystko, co On objawił, ale wierzy się Trójcy (credo Trinitati), to znaczy okazuje się zaufanie Osobom Bożym, aby - w końcu - oddać Im siebie, wierząc w Trójcę (credo in Trinitatem). Oznacza to, że osoba konsekrowana zwraca się do Trójcy, by nawiązać relacje z poszczególnymi Osobami Bożymi, które to relacje nie będą nowe, ale przeżywane w nowy sposób.

Należy dodać, że pojęcie i rzeczywistość konsekracji, posiadając fundamentalne i konstytutywne odniesienie do ewangelicznego pójścia za Jezusem Chrystusem, wyznaczającego specyfikę postawy chrześcijańskiej ${ }^{5}$, łączy się bezpośrednio z rzeczywistością i dynamizmem właściwym dla kultu Trójcy Świętej w Kościele. Innymi słowy, relacje i więzi zachodzące między osobą, która się konsekruje (będąc już włączona do Kościoła rozumianego jako una mystica persona), oraz Osobami Bożymi, sprawiają, że zostaje teologicznie oddzielona od świata, w którym jest, nie należąc już do niego, oraz zwraca się do Pana i Jego królestwa z nowych powodów. Jest w tym wszystkim, oczywiście, obecny podwójny aspekt: negatywny, który wskazuje na zerwanie, oddzielenie, dystans, oraz pozytywny, gdyż niejako dotyczy stanięcia „po stronie” Boga oraz podjęcia służby dla innych, której On jest racją.

Konsekracja zawiera więc typową charakterystykę, która polega na eulogicznym ukierunkowaniu własnego życia w tej samej perspektywie, którą na mocy chrztu zostali w sposób pierwotny naznaczeni wszyscy chrześcijanie jako lud kapłański i kultyczny. Dziewictwo chrześcijańskie staje się zatem stałym uwielbieniem skierowanym do Osób Bożych, którego żywym „tworzywem” jest codzienna egzystencja, ściślej łączona z życiem sakramentalnym. Jeśli żyć po chrześcijańsku oznacza żyć liturgicznie, to życie osób konsekrowanych staje się w najwyższym stopniu życiem kultyczno-liturgicznym.

Ten obiektywny wymiar konsekracji musi, oczywiście, zostać przez człowieka przyjęty w sposób wolny i świadomy, a następnie wprowadzany w życie w jego osobistym i konkretnym przeżywaniu. Jego przyjęcie może się dokonać w sposób zróżnicowany, na przykład przez przyrzeczenie, ślub, obietnicę, w sposób prywatny bądź eklezjalny (śluby zakonne). Z punktu widzenia wartości teologicznej i duchowej konsekracji sam sposób jej wyrażenia nie ma większego znaczenia, gdyż jej konsekwencje i wynikające z niej zobowiązania są w każdym przypadku takie same. Konsekracja zawsze oznacza składanie w Chrystusie i z Chrystusem uwielbienia Ojcu w mocy Ducha Świętego, redukując, na ile to możliwe, pośredniczenie w nim celów doczesnych. Wtedy życie konsekrowane staje się znakiem i wyrazem dynamiki sakramentalnej, przeżywanej w doświadczeniu eklezjalnym, aby świat, jako rzeczywistość wewnętrznie odniesiona do Boga, do Jezusa Chrystusa i do Kościoła, został uświęcony i ukształtowany chrystycznie w Kościele, w mocy Ducha Świętego, po linii działania jedynego zamysłu zbawczego Boga.

\footnotetext{
${ }^{5}$ Por. M. Hengel, Sequela e carisma. Studio esegetico e di storia delle religioni su Mt. 8,21 s. e la chiamata di Gesù alla sequela, Brescia 1990.
} 


\section{Znaczenie dziewictwa konsekrowanego}

\section{i kierunki jego przeżywania}

Teologiczno-liturgiczne rozumienie dziewictwa konsekrowanego zwraca przede wszystkim uwagę na to, że dziewictwo wybrane z miłości do Boga nie tylko traktowane jest jako chciane przez Niego, ale przede wszystkim jako zwrócone do Niego. Wskazuje na to samo pojęcie konsekracji. Innymi słowy, w spojrzeniu na nie i w jego przeżywaniu trzeba uwzględniać, że ma ono sens ,ze względu na królestwo Boże”, o czym mówi Chrystus (por. Mt 19, 11-12), co można równocześnie wyrazić jako „ze względu na Boga” czy też „ze względu na Bożą chwałę”.

Jest więc uprawnione i konieczne stwierdzenie, że chrystologiczna i chrześcijańska specyfika dziewictwa polega na jego ukierunkowaniu na rzeczywistości Boże. Jest to zatem dobrowolna odpowiedź na nieskończoną miłość Trójcy Świętej do ludzi, która koncentruje się na miłości i zmierza do pełnego jej przeżycia.

\section{Konsekracja jako anamnesis}

Na mocy faktu, że konsekracja dziewictwa w ramach Ecclesia Dei jest działaniem liturgicznym, mimo że nie jest sakramentem w sensie ścisłym, można stwierdzić, że dziewictwu niewątpliwie przysługuje charakterystyka właściwa dla anamnesis liturgicznej, to znaczy ,pamiątki”. Anamneza stanowi formalne wypełnienie - ze strony Kościoła - tego, czego nauczał Chrystus. Oczywiście, w ciągu wieków Kościół dojrzewał w swojej świadomości odnośnie do pragnień i nakazów Chrystusa. To samo dotyczy pojedynczego wierzącego, który dojrzewa w rozumieniu tego, czego Chrystus od niego oczekuje. W pewnym sensie sam wysiłek interpretacji jest integralną częścią samego wypełnienia. Różne pokolenia chrześcijan, czego odzwierciedleniem są na przykład rozmaite tradycje liturgiczne, kontynuowały także dzieło interpretacji wydarzenia zbawienia zamkniętego w dziewictwie konsekrowanym. Dziewictwo konsekrowane jest bowiem pamiątką niektórych szczególnych etapów historii zbawienia. W dzisiejszym rozumieniu można wyodrębnić w nim następujące odcienie anamnetyczne.

\section{Anamneza tajemnicy oblubieńczo-paschalnej}

Każde wydarzenie zbawcze jest anamnezą ośrodka i streszczenia historii i tajemnicy zbawienia, którym jest misterium paschalne Chrystusa. Kościół, pogłębiając rozumienie liturgii i życia chrześcijańskiego, stale odwołuje się do tego misterium, będąc stale świadomy, że wielość jego aspektów nie została jeszcze w pełni pogłębiona i wprowadzona w życie. Ciągle odkrywa się jakiś jego nowy aspekt. Jeśli chodzi o dziewictwo konsekrowane, to w ostatnim czasie w teologii i liturgii zwraca się mocno uwagę na to, że jest ono rzeczywistością anamnetyczną miłości między Chrystusem i Kościołem, a więc oblubieńczego zjednoczenia między Chrystusem Oblubieńcem i Kościołem Oblubienicą. W dziewicy konsekrowanej odnawia się 
więc jakby „w miniaturze” to, co dokonuje się w Kościele, w taki sposób, że osoba konsekrowana, na mocy misterium paschalnego, którego jej życie nosi wyciśniętą rzeczywistość ożywiającą: jest równocześnie dziewicą, oblubienicą, matką.

W tym kontekście oblubieńczo-paschalnym jest zatem zrozumiałe, że Chrystus jest nazywany - ponieważ nim jest - Oblubieńcem dziewicy, a dziewica konsekrowana - oblubienicą Chrystusa. Wyłaniają się tutaj dwa pryncypia: ze strony osób, które konsekrują się jest konieczne, aby nie zawierały małżeństwa oraz żyły w czystości, ze strony Chrystusa stwierdza się, że w przypadku tak wybranego dziewictwa On jest Oblubieńcem.

Urzeczywistniając te zasady, dziewica konsekrowana, będąc - w swoim bycie - „pamiątką” oblubieńczej miłości Chrystusa do Kościoła, sama jest znakiem tego, co urzeczywistnia się w „dzisiaj” eklezjalnym. Utrwala ona zatem zbawczą przeszłość miłości Chrystusa do Kościoła. Staje się ona znakiem i rzeczywistością oblubieńczego wydarzenia „Chrystus-Kościół”. Ten znak jest wielowymiarowy, ponieważ zarówno wskazuje na określone rzeczywistości należące do przeszłości zbawczej, to znaczy misterium paschalne, jak i antycypuje to, co zrealizuje się w przyszłości, czyli wypełnienie eschatologiczne. Ze swej strony Chrystus łączy się z dziewicą przymierzem oblubieńczym, aby uczynić ją płodną swoim słowem i swoją łaską. To przymierze urzeczywistnia więc to, co zapowiada i oznacza sakrament małżeństwa.

Nad całą tą rzeczywistością znajduje się fakt wyrażony językiem biblijnym: „Chrystus kocha Kościół, swoją Oblubienicę” (Ef 5, 25). Dar, który Chrystus na krzyżu składa z siebie Ojcu, oraz, w mocy Ducha Świętego, Kościołowi, powtarza się w sposób anamnetyczny w celebracji dziewictwa konsekrowanego za pośrednictwem łaski Chrystusa, która oznacza obecność Chrystusa względem Jego dziewic i czynny dar Ducha Świętego. Przez konsekrację dziewictwa zostaje zapoczątkowana w dziewicy anamneza oblubieńczej tajemnicy Chrystusa i Kościoła, która zrealizowała się na krzyżu.

Anamneza niektórych etapów historii zbawienia

Oczywiście, rzeczywistość tajemnicy oblubieńczej Chrystusa i Kościoła, związana z misterium paschalnym, jest częścią historii zbawienia. W tym miejscu chcemy zwrócić uwagę na niektóre fakty, które łączą konsekrację dziewic z innymi etapami historii zbawienia. Anamneza liturgiczna oznacza bowiem związanie dziewictwa konsekrowanego z przeszłością i przyszłością zbawczą.

Dziewica chrześcijańska, właśnie jako dziewica, jest znakiem transcendentnym i obrazem eschatologicznym. W dziewicy chrześcijańskiej dokonuje się zasadnicza antycypacja historii zbawienia w jej fazie eschatologicznej. Są w niej antycypowane wieczne gody Chrystusa i Kościoła, ponieważ przymierze, to znaczy więź miłości między Chrystusem i dziewicą, realizuje już to, co zapowiada małżeństwo chrześcijańskie. Dla liturgii dziewictwo konsekrowane nie tylko stanowi część 
historii zbawienia, tak że w „dzisiaj” liturgicznym brzmi nowa pieśń ogłaszająca mirabilia Dei spełniające się w dziewicy, która się konsekruje, lecz jest ono również anamnezą głównych etapów zbawienia. Dziewica, od chwili, w której jest powołana przez Osoby Boże, aż do chwili, gdy zwieńcza swoje ziemskie życie, celebrując wraz z paschą chrześcijańską szczęśliwe przejście do niebieskiego Oblubieńca, jest włączona w historię zbawienia, w której „liturgicznie i anamnestycznie” celebruje oraz wciąż na nowo przeżywa to, co Trójca Święta dokonała dla dobra ludzkości.

Powołanie wzbudzane przez Chrystusa jest zawsze odwołaniem się do prymatu inicjatywy Boga, który chce, aby dziewica postępowała w „bojaźni Bożej” i cała w sposób osobowy była odpowiedzią liturgiczno-egzystencjalną na dar dziewictwa, dawany przez Boga niektórym osobom. Duch Święty jest obecny w dziewicy konsekrowanej, aby mogła prowadzić życie przyozdobione ,prudens modestia, sapiens benignitas, gratis lenitas, casta libertas", a zarazem, wciąż na nowo odnawiając zbawczy etap chrztu, coraz bardziej upodabniała się Chrystusa jako Oblubieńca Kościoła.

Przylgnięcie do zamysłu zbawienia, konkretyzując się w darze dziewictwa dobrowolnie przyjętego, sprawia, że dziewica staje się trwałą anamnezą wierności przymierza Boga w stosunku do ludzkości, usankcjonowanego „raz na zawsze” w misterium paschalnym. To, co działanie liturgiczne wyraża za pośrednictwem słów i gestów, to zawiera w sobie, uwypukla i prowadzi do dojrzałości liturgia-życie. Język liturgiczny nie jest językiem pustym, pozbawionym sensu, ale jest językiem, który ontologicznie aktualizuje to, co jest przedmiotem modlitwy, a tam, gdzie człowiek usuwa pojawiające się przeszkody, rzeczywiście się realizuje. Dzieje się to mocą Ducha Świętego, dlatego spojrzenie na dziewictwo konsekrowane prowadzi nas do bezpośredniego związania go z epiklezą.

\section{Konsekracja jako epiclesis}

Jeśli dziewictwo nie jest owocem Ducha Świętego, to jest pozbawione znaczenia. W sensie zaś pozytywnym należy powiedzieć, że znaczenie teologiczno-liturgiczne konsekracji dziewictwa jest nieodłączne od pogłębienia obecności i działania Ducha Świętego. To działanie jest wielowymiarowe. Można wprost powiedzieć, że każda poszczególna chrześcijańska konsekracja dziewictwa jest znakiem działania Ducha Świętego.

Dar Ducha Świętego ze względu na upodobnienie do Chrystusa

Święty Cyryl Jerozolimski słusznie zauważył: „Gdy kiedy w wolnym czasie przyszła ci myśl o czystości lub dziewictwie, wiedz, iż to była nauka Ducha Świętego"6. Cała tradycja Kościoła przypomina, że konsekracja dziewictwa ma nierozerwalny związek z Duchem Świętym, który udziela swoich darów dla określonych działań w życiu chrześcijańskim.

${ }^{6}$ Cyryl Jerozolimski, Katecheza 16, 19, [w:] Katechezy przedchrzcielne i mistagogiczne, thum. W. Kania, Kraków 2000, s. 266. 
Dar Ducha Świętego sprawia zatem, że człowiek wchodzi na drogę całkowitego oddania siebie Bogu. Do Niego należy inicjatywa i On udziela się jako pierwszy. Z moralnego punktu widzenia dar z siebie domaga się odpowiedzi, polegającej na pełnym oddaniu siebie. Dlatego osoba, która przez konsekrację otrzymuje namaszczenie Ducha Świętego, powinna zdecydowanie wejść na drogę wytrwałości, która stanowi część jej methexis, o której będzie mowa w dalszej części. Duch Święty nawiązuje relację z osobą, która ofiaruje swoją czystość, czyli „zwraca się” do tej osoby, stymulując jej doskonałość i wzrost w doskonałości. Dziewictwo konsekrowane staje się więc świadectwem działania, przez które Duch Święty przyjmuje osobę i jej działania jako swoją własność, aby napełnić ją swoim boskim życiem, jako mocą (kinesis), wzbudza zapał, który pozwala jej wytrwać w podjętych zobowiązaniach oraz okazuje jej pomoc w osiągnięciu pełnej realizacji i wykorzystania swojej mocy, aby wejść w synergię z zamysłem Bożym.

„Przyjęty dar” dziewictwa chrześcijańskiego jest ukierunkowany na świadectwo dawane Chrystusowi-Kościołowi i upodobnienie do Jezusa Chrystusa w Duchu Świętym. Dziewictwo konsekrowane posiada konkretne cele, które w odniesieniu do działania Ducha Świętego mogą być wielorakie. Można mówić o wymiarze chrystologicznym dziewictwa konsekrowanego. „Odrodzeni przez Ducha Świętego”, jak są określane w Kościele osoby konsekrujące swoje dziewictwo, pod Jego impulsem, ofiarują swoją czystość, aby goręcej kochać Chrystusa oraz mocniej i bardziej bezpośrednio z Nim się połączyć, by w ten sposób jaśniało w nich Jego oblicze. Wymiar chrystologiczny jest ściśle związany z wymiarem eklezjalnym. Ponieważ dziewictwo konsekrowane ściślej łączy z Chrystusem, dlatego też łączy z Jego pragnieniami, które dotyczą Kościoła. Pod natchnieniem Ducha Świętego dziewice konsekrowane, dzięki swojej czystości, w szerszym zakresie poświęcają się służbie na rzecz braci. Pieczęć „wspólnoty z Duchem Świętym” (communicatio Spiritus Sancti), jak mówi wspomniany św. Cyryl Jerozolimski ${ }^{7}$, w osobie, która konsekruje swoje dziewictwo, staje się źródłem nowości życia i działania, którego pierwszorzędnym wyrazem stają się cnoty ewangeliczne: miłość, cierpliwość, życzliwość i wdzięczność.

\section{Trwała obecność Ducha Świętego}

Obecność Ducha Świętego w liturgii jest „współnaturalna” z samą rzeczywistością liturgiczną. Ta obecność jest wyjątkowa w działaniu liturgicznym zarówno ze względu na naturę celebracji, jak i wzywanie Ducha Świętego, którego dokonuje euchologia. Ściśle mówiąc, epikleza odnosi się do obecności „wzywanej” w działaniu liturgicznym. Trzeba jednak podkreślić, że jak działanie liturgiczne ma celebratywne „przed” i „potem”, tak również sama obecność Ducha nie może być ograniczona do samej celebracji. Także w dziewictwie Duch Święty nie ogranicza swego działania do wzbudzenia jego wyboru i do modlitwy konsekracyjnej, ale rozciąga swoje

\footnotetext{
${ }^{7}$ Tenże, Katecheza 18, [w:] Katechezy przedchrzcielne i mistagogiczne, s. 314.
} 
działanie na całe życie osoby konsekrującej się, wspierając ją wielorako w składaniu daru z siebie. Epikleza Ducha Świętego, klasycznie wyrażana przy pomocy pojęć „zesłanie/wylanie”, jest mocą i stałością ze względu na dotrzymanie złożonych obietnic, szczególnie obietnicy dziewictwa.

Jest to zatem epikleza Ducha Świętego, która umacnia wolę tego, kto przylega do Chrystusa. Dziewictwo konsekrowane jest owocem Ducha, jest stałością w Duchu, jest pełnym poświęceniem się dla Chrystusa wraz z Duchem Świętym. Dzięki mocy Ducha Świętego dziewictwo konsekrowane staje się duchowym macierzyństwem. Można zatem powiedzieć, że dziewictwo chrześcijańskie jest wzbudzane przez Ducha Świętego; jest konsekrowane i uświęcane Jego obecnością; trwa w czasie, ponieważ jest wspierane Jego działaniem, które wzmacnia wytrwałość, podtrzymuje decyzję oraz ożywia wierność. Jest więc ono celebracją ożywiającego działania Ducha Świętego. On ożywia osoby, które w znaku dziewictwa umacniają odniesienie do Chrystusa i do rzeczywistości eschatologicznych. Dziewictwo dane i ofiarowane jest celebracją Jego trwałego daru, przyjętego po to, by składać siebie w darze i poświęcać się całkowicie Chrystusowi-Kościołowi i Majestatowi Bożemu. Jego obecność i działanie wyzwala serce oraz skłania je do głębszego i idącego coraz dalej zrozumienia rzeczywistości, którą się wybiera i w której się uczestniczy, aby przyjmować ją w wolności i kształtować za jej pośrednictwem wolność osobistą. Duch przywołuje tę rzeczywistość we wnętrzu serc, które ją rozumieją; ożywia jej znak; daje moc wewnętrznym poruszeniom i impulsom dobra, które wynikają ze stałego stanu składania się w darze; ożywia i wewnętrznie odnawia moce złączone z dziewictwem chrześcijańskim. To On jest Tym, który zawsze i w każdej sytuacji może odnowić każde stworzenie przez dar dziewictwa. Stare pryncypium patrystyczne głosi: „Deus etiam copulatus meretricibus, eas vertit in virgines”. On jest źródłem ofiarowania, na mocy którego osoba, która konsekruje się, celebruje z Chrystusem swoje devotio i oblatio. Jednym słowem, kto widzi osobę ozdobioną dziewictwem, widzi znak Ducha Świętego; kto do niej się zbliża, odkrywa tajemnice Ducha Świętego i Jego boskiego działania.

\section{Dziewictwo jako methexis}

Jeśli jest prawdą, że trzy poziomy: mysterium - actio - vita zakładają wzajemne relacje i przenikanie się, to jest również prawdą, że mysterium jest obecne w actio na sposób liturgiczno-celebratywny związany z anamnesis. Innymi słowy, actio oznacza pamiątkę, której przedmiotem jest mysterium. Życie jest otwarte na actio na sposób liturgiczno-celebratywny uczestniczenia (methexis). Jeszcze innymi słowy, vita jest obecna w actio poprzez uczestniczenie. Jednak jest tak samo prawdą, że to, co ontologiczno-witalne, jest obecne i przechodzi od actio do vita, jest również zawsze ożywiane i ukierunkowywane przez liturgiczno-celebratywny sposób uczestniczenia, które ze swej strony jest wyrazem działającej obecności Ducha 
Świętego. Zwracając uwagę na methexis, obecną w dziewictwie konsekrowanym, dokonujemy uwypuklenia tego, co oznacza dziewictwo konsekrowane z punktu widzenia teologiczno-liturgicznego. Dziewictwo zatem nie tylko postuluje rzeczywistość i zrozumienie methexis, ale ono samo jest methexis, czyli uczestniczeniem. Dziewictwo konsekrowane jest methexis wyznawaną i wierzoną, kochaną i przeżywaną, niektórych rzeczywistości-prawd.

\section{Dziewictwo jako methexis ofiarna}

Współpraca w działaniu Ducha Świętego w osobach, które chcą konsekrować się lub które faktycznie konsekrowały swoje dziewictwo i trwają w stanie konsekrowanym, oznacza już methexis ofiarną. Chodzi o to, by uświadomić sobie, że ofiarowanie (oblatio), o ile stanowi element konstytutywny konsekracji, zawiera w sobie przynajmniej podwójny wymiar. Chodzi o ofiarowanie kultyczne, nieoddzielone od ofiarowania egzystencjalno-dynamicznego. Methexis ofiarno-kultyczna wyznacza dziewicy konsekrowanej zasadniczy cel, którym jest uwielbienie Ojca - sine intermissione. Można mówić o specyfice dziewictwa chrześcijańskiego jako jego ukierunkowaniu do Ojca. Ojciec, ze swej strony, jest nagrodą za dziewictwo konsekrowane. Złączone z Jezusem Chrystusem, najwyższym i wiecznym Kapłanem, osoby, które konsekrują swoje dziewictwo, czynią z niego dar ofiarny w chwili konsekracji i przyjmują postawę ofiarowania się w ciągu swego życia.

Celebracja konsekracji dokonuje przejścia od pragnienia, nawet ukrytego, obecnego w głębi osoby, do rzeczywistej zgody wyrażonej słownie i znacząco w „ślubie”, powtarzanym ciągle na nowo. Dar jest ofiarowany w sposób wymienny. Trójca Święta wskazuje na niego w pytaniu liturgiczno-eklezjalnym, a osoba odpowiada swoim ślubem, stawiając się na pozycji ofiarowania liturgicznego. Kontekstem ofiarnym jest Eucharystia, mająca bezpośrednią relację z misterium paschalnym Chrystusa. Trzeba oczywiście pamiętać, że aspekt ofiarno-kultyczny jest przeżywany w życiu konkretnym. Znak liturgiczny przywołuje rzeczywistość przez nią oznaczaną.

Ofiarowanie o charakterze kultycznym wpisane w dziewictwo chrześcijańskie znajduje dopełnienie w tym, że zostaje ono ukierunkowane na cele o charakterze ofiarno-działaniowym. Jest to równoznaczne z tym, że między działaniem liturgicznym i życiem liturgicznym nie ma żadnej dychotomii, gdyż oznaczałoby to pozbawienie sensu samej rzeczywistości celebrowanej. Dziewice są wezwane do trwałego poświęcenia się kultowi Bożemu i służbie braciom. Oznacza to, że dziewictwo chrześcijańskie jest wtedy autentyczne, gdy tajemnica dziewictwa, skoncentrowanego na głębokiej i wyłącznej miłości, poprzez celebrację in facie Ecclesiae, w tajemnicy Chrystusa Dziewicy-Oblubieńca, ze swej strony obejmuje całe życie dziewicy. Dziewictwo chrześcijańskie wpisuje się w każde działanie dziewicy. Urzeczywistnia się w ten sposób proces przenikania między wyrażeniem kultyczno-ofiarnym oraz ofiarowaniem działaniowo-egzystencjalnym. Celebracja staje się wyrażeniem kultyczno-eklezjalnym stanu dziewiczego dobrowolnie przyjętego jako dar, który 
ma przynieść owoce, ofiarną dyspozycją pełnienia dobrych uczynków, gotowością zachowania niepodzielnego serca, aby móc go dać wszystkim, przyczynianiem się do budowania królestwa Bożego, dlatego też kształtuje życie dziewicy do przyjęcia postawy egzystencjalno-ofiarnej.

\section{Methexis służebna}

„Dziewictwo, aby być cnotą, zakłada decyzję potwierdzoną ślubem pozostania w stanie dziewiczym" - stwierdza św. Tomasz z Akwinu. Zakłada to, że konsekracja dziewictwa domaga się dopełnienia przez przyjęcie postawy służebnej, w której wyraża się jego osobowy i eklezjalny charakter. Dziewictwo konsekrowane łączy się z uczestniczeniem w trwałości i ciągłości stanu dziewiczego. Aby wypełnić taką posługę na rzecz dziewictwa świadomie chcianego i przyjętego, dziewica potrzebuje wiary i wierności. Gdy stan służebny jest zakorzeniony w sercu osoby konsekrowanej, wtedy rzeczywistość liturgiczno-egzystencjalna prowadzi dziewicę konsekrowaną do uświadomienia sobie, że znaczenie teologiczno-liturgiczne dziewictwa konsekrowanego polega na byciu dla innych. W ten sposób stale powraca się do stanu i postawy służby, którą każda osoba, konsekrująca swoje dziewictwo, powinna przeżywać i którym powinna niejako „oddychać i poruszać się”. Gest służby wypływa $\mathrm{z}$ bycia konsekrowanym, skierowanym i poświęconym na rzecz Majestatu Bożego. Źródłem diakoni, które ma podjąć i wypełnić dziewica konsekrowana, jest Duch Święty. Jej celem jest Bóg, Jezus Chrystus, Kościół, zależnie od okoliczności i sytuacji, które powinna wytrwale rozeznawać.

Można więc powiedzieć, że zasadnicze znaczenie w konsekracji dziewictwa posiada moment celebratywno-obrzędowy. Nie mniejsze znaczenie posiada jednak moment wydarzeniowo-egzystencjalny, który na ogół jest nazywany stanem dziewiczym. Z momentu celebratywnego czerpie on swoje trwanie, spójność i moc. $\mathrm{Z}$ celebracji liturgicznej wypływa życie mające odniesienie liturgiczne, w którym methexis służebna, która została wyznana i objęta modlitwą w czasie celebracji, staje się rzeczywistością przeżywaną i działającą w ,"potem” celebratywnym. Jest to równoznaczne ze stwierdzeniem, że uczestniczenie liturgiczne jest sposobem, poprzez który życie dziewicy konkretnie i rzeczywiście wpisuje się w wydarzania zbawcze.

\section{Methexis płodna}

Matka chrześcijańska, która nie ma serca dziewiczego, nie jest w stanie wypełnić swojej misji i swojego powołania. Dziewica konsekrowana, jeśli nie ma serca macierzyńskiego, niweczy swoją konsekrację. Dziewictwo konsekrowane domaga się specyficznego dopełnienia w macierzyństwie. Jest to macierzyństwo w Duchu Świętym; oczywiście, jest to macierzyństwo płodne. Aby rodzić do życia lub przywracać do łaski, dziewice chrześcijańskie, właśnie jako dziewice, mogą być

\footnotetext{
${ }^{8}$ Tomasz z Akwinu, Summa theologiae, II-II q. 152 a. 3 ad 4.
} 
matkami duchowymi. Miłość dziewicy konsekrowanej jest miłością całościową. Jako cel ma ona Ojca. Płodność jest uczestniczeniem dziewic w Ojcu, który jest dla nich wszystkim, w mocy Ducha Świętego. Jest to płodność, którą ozdobiona dziewica konsekrowana, staje się znakiem uczestniczenia w rodzącej miłości Boga.

Kondycja dziewiczości konsekrowanej różni się od wszystkich innych form dziewictwa niekonsekrowanego. Relacja, jaka nawiązuje się między dziewicą konsekrowaną i Osobami Bożymi, przechodzi przez ożywiającą aktualizację więzi oblubieńczej, całkowicie typicznej, z Jezusem Chrystusem. Ta relacja duchowo-oblubieńca czyni dziewictwo konsekrowane płodnym w taki sposób, że - w miłości do innych - „oblubienicy Chrystusa” nie zostają narzucone żadne ograniczenia, intensywność i głębia, ale tylko forma, to znaczy może ona i ma kochać w Chrystusie i ze względu na Chrystusa. Jej płodność uczestniczy w ten sposób w promieniującej witalności życia, którego źródłem jest sam Chrystus Pan. W tym miejscu ukazuje się inny wymiar uczestnictwa, którym jest ozdobiona dziewica konsekrowana, a mianowicie - jej miłość jest większa od wszelkiej miłości naturalnej; jej płodność jest bardziej intensywna niż wszelka płodność naturalna; jej macierzyństwo jest głębsze i szersze od macierzyństwa fizycznego. Dzieje się tak dlatego, że bardziej niż inni uczestniczy ona w miłości Jezusa Chrystusa, Boga-Człowieka, do ludzkości.

Chrześcijańska konsekracja dziewictwa czyni samo dziewictwo wydarzeniem sakralnym, które - analogicznie do wydarzeń zbawczych, którymi są sakramenty - ma w sobie potrójny dynamizm związany odpowiednio z rzeczywistością pamiątki, obecności Ducha Świętego oraz uczestniczenia liturgicznego. Jest to równoznaczne $\mathrm{z}$ uświadomieniem sobie, że od obrzędowej jedności konsekracji dziewiczości z Eucharystią trzeba przejść do jedności liturgiczno-egzystencjalnej, która łączy życie dziewicze ze znaczeniem konsekracyjnym obecnym w samej Eucharystii. Można więc powiedzieć, że chodzi o przejście od momentu obrzędowego do wydarzenia egzystencjalnego. Trzeba oczywiście pamiętać, że dziewictwo chrześcijańskie nie jest wolne od pewnych napięć, które dotyczą: pragnienia osiągnięcia głębokiego upodobnienia do Chrystusa, wzoru dziewictwa eklezjalnego; codziennego ryzyka nieumiejętności doprowadzenia do ostatecznych konsekwencji praktycznych wymagań życia dziewiczego; oczekiwania przyszłego królestwa, w którym - jak ukazuje Apokalipsa - orszak dziewic zmierza do spotkania z Barankiem oczekującym na wszystkich na ołtarzu w niebie. Chrześcijańska konsekracja dziewictwa zakłada pokój i radość w trwałym zaangażowaniu w życie mające charakter pamiątki obecnej w rzeczywistości dziewiczej, by dojść, za natchnieniem Ducha Świętego, do ofiarnego i służebnego uczestniczenia, o którym wyżej była mowa.

Należy dodać, że liturgia w swoim wymiarze zstępującym jest historią zbawienia, czyli tajemnicą celebrowaną za pośrednictwem życia; w swoim wymiarze wstępującym jest następnie samym życiem, które zmierza do momentu obrzędowo-celebratywnego 
w taki sposób, że tajemnica osiąga swój cel ostateczny, to znaczy oddaje prawdziwy kult Bogu. Dziewictwo chrześcijańskie jest prawdziwym dziewictwem konsekrowanym w takiej mierze, w jakiej łączy w sobie te dwa wymiary. Aspekt kultyczny dziewictwa chrześcijańskiego zasługuje na bardziej powszechne i specyficzne traktowanie. Jest jednak pewne, że w skutecznym wspominaniu (anamnesis) wspaniałych dzieł Bożych (mirabilia Dei), życie dziewicze zostaje włączone w zamysł urzeczywistniany przez Trójcę Świętą (oikonomia) i ofiarowane Panu, aby na mocy wzywanej obecności (epiclesis) i działania Ducha Świętego każda chwila życia i każde doświadczenie dziewicy stały się okazją, motywem i miejscem zbawienia. Ludzka współpraca z działaniem Bożym sprawia, że chrześcijańska konsekracja dziewictwa, będąca darem i łaską Bożą, staje się codzienną i stopniową manifestacją ludzko-chrześcijańskiej wartości dziewictwa.

Liturgia-życie, wypływające z działania liturgicznego, w którym jest w pełni celebrowane mysterium, przekształca życie osoby dokonującej konsekracji dziewictwa w ofiarę kultyczną. Wraz z działaniem liturgicznym zaczyna się proces dojrzewania ofiarnego, które prowadzi do ofiarowania w coraz większym stopniu swojego bytu na chwałę Trójcy Świętej. W ten sposób wytwarza się w końcu coś w rodzaju instynktu duchowo-nadprzyrodzonego, który dynamicznie rozwija się i ciągle wzrasta, aż osoba konsekrowana dojdzie do kosztowania ojcostwa i macierzyństwa duchowo-nadprzyrodzonego.

\section{Summary}

\section{Following God's betrothed. Theological and liturgical meaning of the consecrated virginity}

The article deals with the subject of searching the nature of the consecrated virginity in the Church. This analysis is based on the theological and liturgical aspects defined by Ordo Consecrationis Virginum and Ordo Professionis Religiosae. Therefore we take the assumption that the most appropriate criterion of its interpretation in the Christian reality can be found in the principle: lex orandi - lex credendi. From this perspective the consecrated virginity is perceived as positive reality as far as faith celebration is concerned. The liturgy describes virginity as a gift offered to man by God's people. Faith is also a prize and through the liturgy it is able reach its highest point. Virginity glorified in the Christian reality becomes a present as well as it is not only connected with but also filled with faith. Virginity consecrated under liturgical circumstances gains both ontological and dynamic features typical of worship. This sequentially allows to understand that virginity is not simply the result of ascetic effort, nor it is the physical adornment of a believer. In fact it spreads on the whole person who is being revived by sacraments. It makes them improve by personal commitment marking their route through the history of salvation.

\section{Keywords}

Catholic Church, consecration, liturgy, theology, virginity 